\title{
Some Mechanistic Aspects on Fmoc Solid Phase Peptide Synthesis
}

\author{
Diego Arantes Teixeira Pires - Marcelo Porto Bemquerer • \\ Claudia Jorge do Nascimento
}

Accepted: 21 August 2013/Published online: 29 August 2013

(C) Springer Science+Business Media New York 2013

\begin{abstract}
Peptides are biomolecules that may have several biological activities which makes them important to the environment in which they operate. Sometimes it is necessary for larger amounts of peptides to carry out some studies, like biological tests, NMR structural research or even interaction studies between peptides with other molecules. Expression can be an alternative for that. However, synthesis is specially useful when unnatural modifications or introduction of site specific tags are required. Synthetic peptides have been used for different studies such as cell signaling, development of epitope-specific antibodies, in cell-biology, biomarkers for diseases etc. Many different methodologies for peptide synthesis can be found in the literature. Solid phase peptide synthesis (SPPS) has been largely used and can be an excellent alternative to achieve larger quantities of these biomolecules. In this mini review, we aim to describe the SPPS and explain some of the
\end{abstract}

D. A. T. Pires - M. P. Bemquerer

Embrapa Recursos Genéticos e Biotecnologia, Parque Estação Biológica PqEB Av. W5 Norte (Final), P.O. BOX 02372,

Brasília, DF 70770-917, Brazil

D. A. T. Pires - C. J. do Nascimento $(\square)$

Instituto de Química, Universidade de Brasília, Campus

Universitário Darcy Ribeiro Instituto de Química Asa Norte,

P.O. BOX 04478, Brasília, DF 70919-970, Brazil

e-mail: claudia.j.nascimento@gmail.com

\section{A. T. Pires}

Instituto Federal de Educação, Ciência e Tecnologia de Goiás, Rua São Bartolomeu, Vila Esperança, Luziânia, GO 72811-580, Brazil

\section{J. do Nascimento}

Instituto de Biociências, Universidade Federal do Estado do Rio de Janeiro, Av. Pasteur, 458 - Urca, Rio de Janeiro,

RJ 22290-240, Brazil mechanistic aspects and reagents involved in all phases of the synthesis: the use of resin, the ninhydrin test, some of the protecting groups, coupling reagents for peptide bond formation and the cleavage process.

Keywords Peptides $\cdot$ SPPS $\cdot$ Fmoc $\cdot$ Chemical mechanisms

\section{Introduction}

Peptides are widespread molecules in nature, and they have several biological activities such as antimicrobial (Hancock and Scott 2000; Zasloff 2002), antithrombotic (Menezes et al. 2011), opioid (Goldberg 2010), antioxidant (Zhang et al. 2011) and so on. Therefore, peptides are important to the environment in which they operate and also as an object for the development of new drugs (Brogden 2005). Peptides are also becoming increasingly important in materials science due to their self-assembling properties (Bong et al. 2001; Chen 2005).

Usually, the amount of peptide that can be naturally extracted from plants, animals and microorganisms is too small, allowing only a few studies, as the initial identification and characterization of the biomolecule. To carry out some other studies, such as biological tests, NMR structure determination and interaction studies, it is necessary to acquire larger amounts of the molecule, which can be difficult to achieve by extractions from the natural source. Expression is a good choice if no changes in the structure are required. If this is the situation, a solution to this problem can be peptide synthesis.

The peptide synthesis may be carried out both in liquid (Takahashi and Yamamoto 2012; Gravert and Janda 1997) and solid-phase (Fields and Noble 1990; Chan and White 
2000; Benoiton 2005; Schnolzer et al. 2007). The solidphase synthesis has been the most widely used (Naidoo and Rautenbach 2012; Elsawy et al. 2012; Zhang et al. 2012; Hibino and Nishiuchi 2012; Aucagne et al. 2012; Amblard et al. 2006), as it has some advantages (such as better overall yield and fewer by-products) and it has greater acceptance when compared to the liquid-phase synthesis. More recently, the use of ionic liquids in peptide synthesis need also to be considered as a medium both for solidphase and liquid-phase synthesis (Plaquevent et al. 2008; Tietze et al. 2012).

The solid-phase peptide synthesis starts with a resin which is insoluble under the conditions of the synthesis, usually a copolymer of polystyrene with $1 \%$ divinylbenzene sometimes grafted with polyethylene glycol (Zalipsky et al. 1994), and which must also have an anchor for the synthesis to be carried out in the solid support (Merrifield 1963; Albericio 2004; Marquardt and Eifler-Lima 2001). In this synthesis, a process of washing and filtration of the sample is performed at the end of each reaction step. Thus, excess of reagents, solvents and any other compounds not bound to the resin are removed (Marquardt and Eifler-Lima 2001). This procedure can prevent unwanted reactions, allowing higher yields and producing cleaner synthesis (Marquardt and Eifler-Lima 2001).

Among the strategies for the synthesis of peptides on solid-phase, Fmoc (fluorenylmethyloxycarbonyl) and Boc (tert-butyloxycarbonyl) are most used (Miranda and Alewood 1999; Hudson 1988). In this work, our focus is the Fmoc strategy for solid phase peptide synthesis (SPPS).

Different information about the SPPS can be found in the literature (Jensen, 2013; Naidoo and Rautenbach 2012; Elsawy et al. 2012; Zhang et al. 2012; Hibino and Nishiuchi 2012; Merrifield 1963; Najera 2002; Isidro-Llobet et al. 2009), including reviews that describe details of the experimental procedures on SPPS (Shelton and Jensen 2013; Amblard et al. 2005, 2006). In all of them the main purposes are more related to practical procedures. This short review presents an overview of solid-phase peptide synthesis, describing the reagents involved throughout the chemical steps and the reaction mechanisms related to each part of the synthesis. Our focus is not on the details of the experimental procedure, but on the mechanistic aspects, describing basic mechanisms of the reactions involved in the synthesis.

\section{Resin and Protecting Groups}

In the synthetic Fmoc methodology, all amino acid derivatives used during the synthesis have the 9-fluorenylmethyloxycarbonyl (Fmoc, Fig. 1) as a protecting group. It is a temporary protecting group of the amino function, removed at each step of the synthesis, being a base labile group (Isidro-Llobet et al. 2009; Carpino and Han 1972; Carpino 1987; Machado et al. 2004), which is normally removed by piperidine or the most recently added alternative to piperidine: 4-methylpiperidine (same efficiency in Fmoc group removal as piperidine) (Hachmann and Lebl 2006). 4-methylpiperidine has become an alternative to piperidine since the latter is a controlled substance and its distribution is carefully monitored (Hachmann and Lebl 2006). Fmoc can also be removed by stronger organic bases such as 1,8-diazabicyclo[5.4.0]undec-7-ene (DBU), but in a condition more prone to side reactions (Mergler and Dick 2005). This lability is due to the fact that the removal of the acidic hydrogen of the Fmoc (highlighted in red in Fig. 1) generates a conjugated base stabilized by resonance (IsidroLlobet et al. 2009). In addition to the temporary protecting group, there are also the permanent protecting groups of the amino acid residue side chains - the $t$-butyl, $O$ - $t$-butyl, trityl (Trt), 2,2,4,6,7-pentamethyldihydrobenzofuran-5-sulfonyl (Pbf), t-butyloxycarbonyl (Boc) groups (structures shown in Fig. 2), which remain linked throughout all stages of the synthesis, being removed only in the last step, the cleavage of the peptidyl-resin linkage.

Both permanent and temporary protectors will ensure the reaction of Fmoc-amino acids only in the site of interest

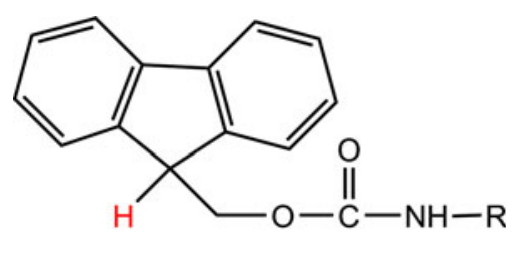

Fmoc

Fig. 1 Structure of Fmoc (Color figure online)
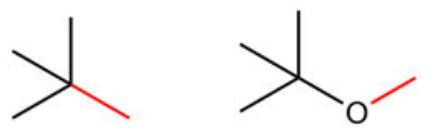

$t$-butyl

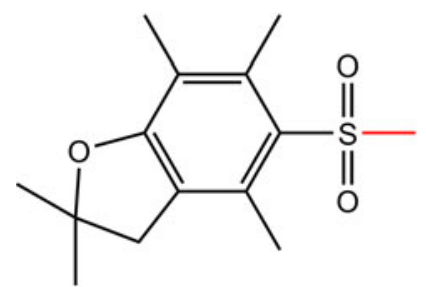

Pbf

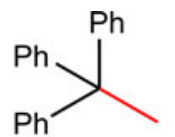

Trityl (Trt)

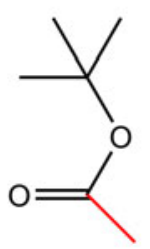

Boc
Fig. 2 Structures of $t$-butyl, O-t-butyl, Trt, Pbf and Boc (permanent protecting groups for the amino acids side chain). In red the carbon that is attached to the amino acid (Color figure online) 
Fig. 3 Structure of the resin used throughout the synthesis. The amino group is shown in red and $P$ is the polymer chain from the resin (Color figure online)<smiles>C=NC(c1ccc(OCC(=O)NC(c2ccc(C)cc2)c2ccc(-c3ccccc3)cc2)cc1)c1ccc(OC)cc1OC</smiles>

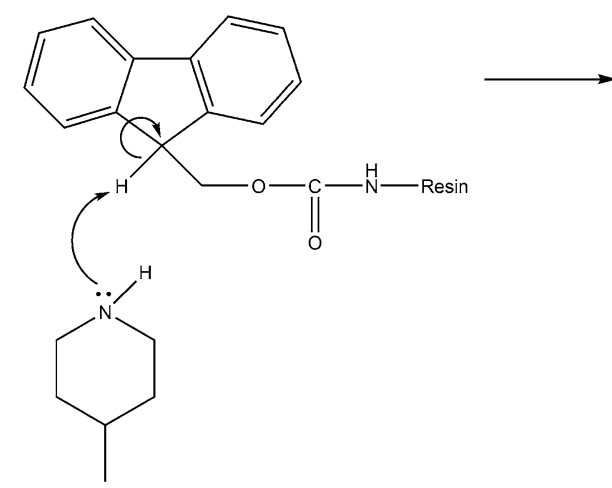<smiles>O=C(NCCOC(=O)c1ccccc1)NCCc1ccccc1-c1ccccc1</smiles>
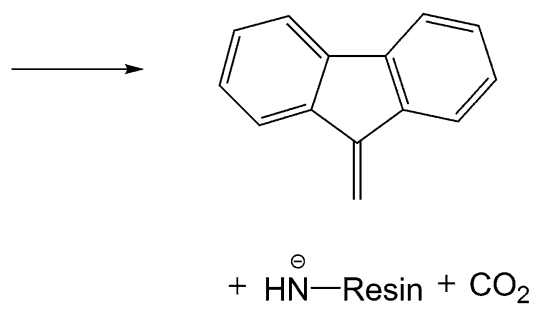

4-Methylpiperidine

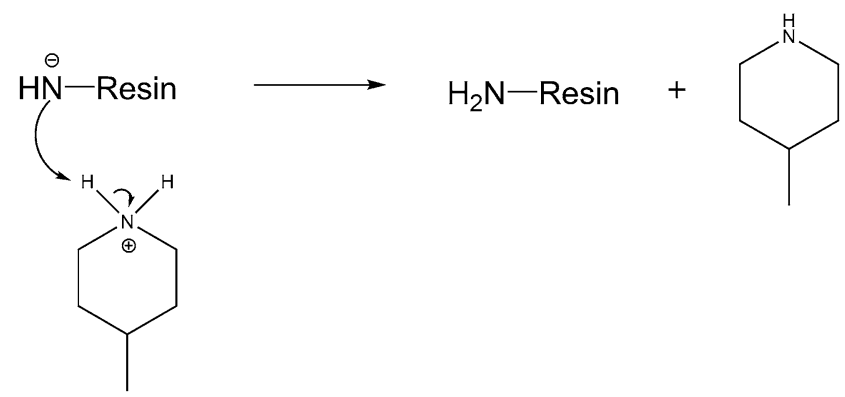

Fig. 4 Removal of the Fmoc group by 4-methylpiperidine for the formation of a free $-\mathrm{NH}_{2}$ (Chan and White 2000)

for the formation of the peptide bond. It helps to prevent secondary reactions, such as the incorporation of dipeptide derivatives instead of an amino acid derivative. In addition, it may help in the final purification of the product due to smaller amount of undesired products.

The synthesis can be performed in a syringe with a filter to retain the resin that is made either of polypropylene or of a sintered glass material. As reported before, the resin is an insoluble and inert support. Nevertheless, it is derivatized with a linker to furnish proper acid lability to the peptidylresin linkage by the presence of electron-releasing groups.
Also, the linker defines the C-terminal functional group. A Rink amide linker can be used as a support for the solid phase, as well as a Pal linker and a Sieber linker, which led to C-terminal peptide amides (Howl 2005). On the other hand, the Wang, Sasrin, 4-(4-hydroxymethyl-3-methoxyphenoxy)butyric acid (HMPB), and 2-chlorotritryl linkers can be used for the synthesis of free C-terminal peptide acids (Howl 2005; Gońgora-Benítez et al. 2013). The sasrin and the 2-Chlorotrityl chloride resin are appropriate for the synthesis of side-chain protected peptide fragments by being labile to dilute acids. Also, the 2-Chlorotrityl 
<smiles>[R]C[N+](CCC)(CCC)C1(O)C(=O)c2ccccc2C1=O</smiles>

Ninhydrin

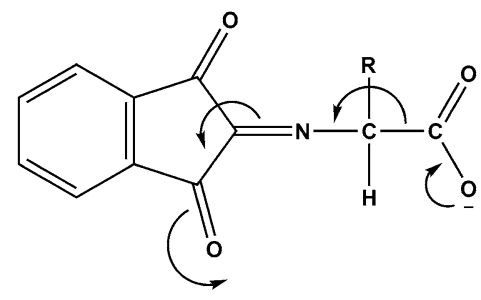

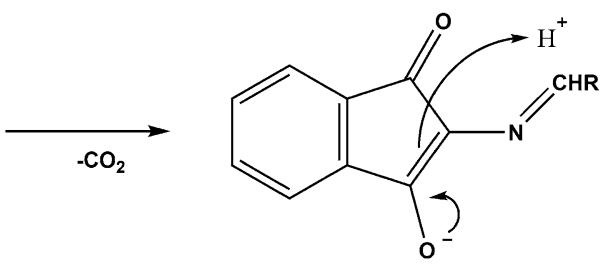<smiles>[R]=C=NC1C(=O)c2ccccc2C1=O</smiles>

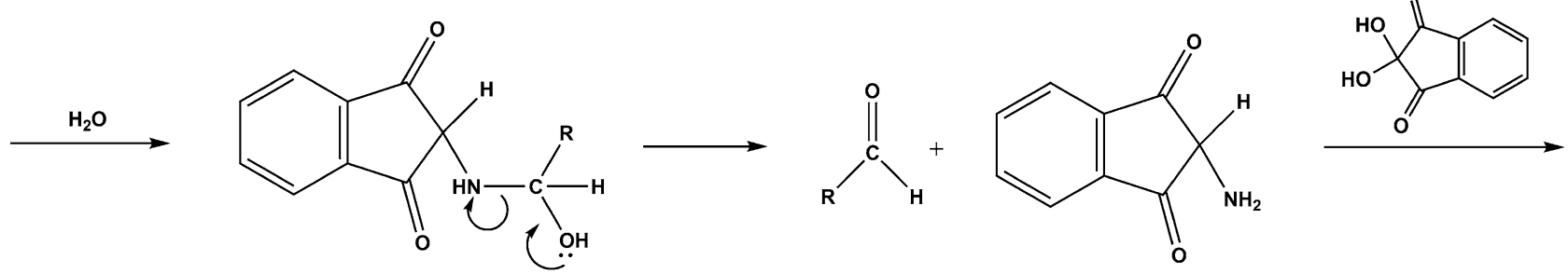<smiles></smiles>

Ruhemann`s Blue

Fig. 5 Mechanism for the ninhydrin reaction with an $\alpha$-amino acid with a primary amino group to form the Ruhemann's blue (Friedman 2004; McCaldin 1959)

chloride resin is employed for the synthesis of C-terminal peptide acids, which may be important as modified peptide drugs, such as the somatostatin-analogue octreotide (Tailhades et al. 2010).

In this work, the synthesis will be exemplified by using the Rink amide resin (MDHA), whose linker structure is shown in Fig. 3. Since many peptides are naturally found in the amidated form and due to the fact that C-terminal amides are generally more stable to degradation than C-terminal acids, a resin with an $-\mathrm{NH}_{2}$ group (as Rink Amide) is very widely employed. The coupling of the first Fmoc-amino acid will occur at the amino group of the resin, forming an amide bond and it will be described together to the peptide bond formation.

\section{Removing the Temporary Protecting Group Fmoc}

The Fmoc group must be removed to furnish free amino groups that will react with activated carboxyl components for peptide bond formation. For this purpose, the resin must be first washed with 2-propanol and $N, N$-dimethylformamide, DMF, for the removal of soluble impurities (Chan and White 2000; Benoiton 2005; Marquardt and EiflerLima 2001). Both the 2-propanol and DMF can be removed from the reaction vessel by filtration at reduced pressure. For removing the Fmoc protecting group from the resin, the preferable organic base now is 4-methylpiperidine, as previously explained. According to standard procedures deprotection can be conducted in a solution of 

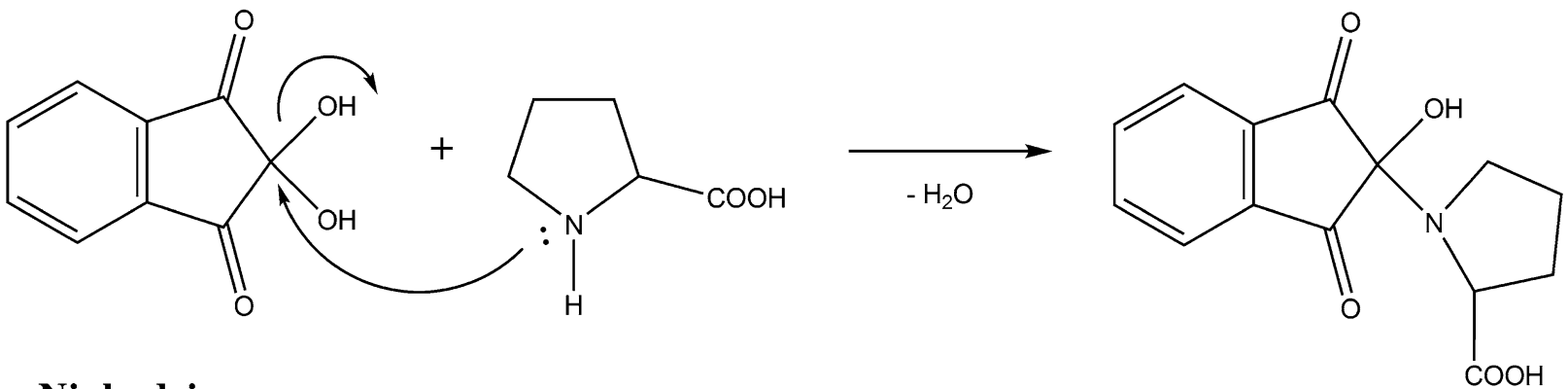

\section{Ninhydrin}

\section{Proline}
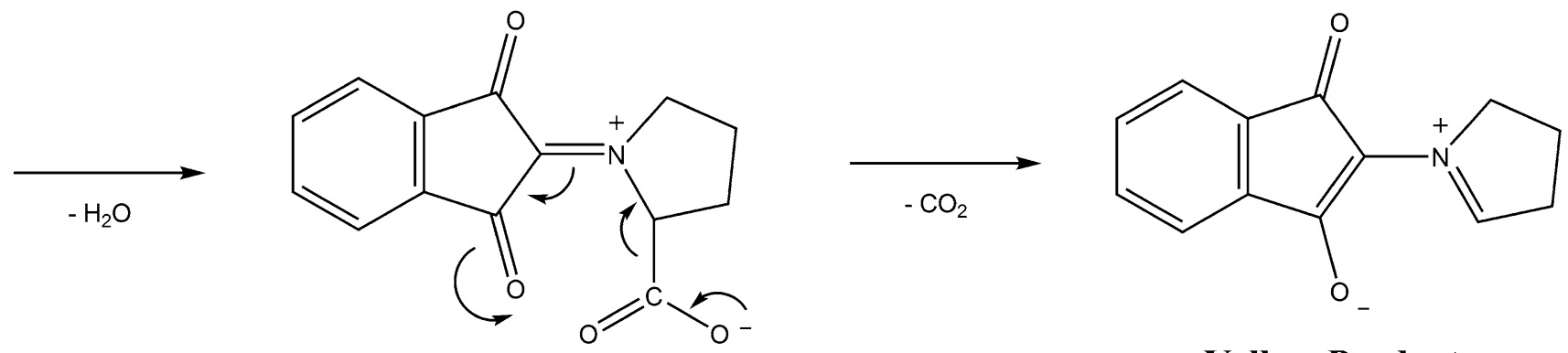

Yellow Product

Fig. 6 Mechanism for the ninhydrin reaction with proline (Kaupp et al. 2002; McCaldin 1959)

4-methylpiperidine in DMF (20-30\% by volume) for 1-5 min (2 times). Then, the resin can be washed again with 2-propanol and DMF. Finally, the resin has to be washed with dichloromethane (DCM) to easily dry the grains. Alternatively, it can be washed with a mixture of methanol/dichloromethane (MeOH/DCM), which helps to prevent losses of resin sticking to the glass or plastic syringe. Fmoc deprotection by piperidine or by 4-methylpiperidine is usually fast and clean. Slow kinetics and low Fmoc deprotection yields are clear indications of peptide aggregation (Remuzgo et al. 2009).

The reaction mechanism for the removal of Fmoc by 4-methylpiperidine is shown in Fig. 4. Initially the acidic proton from the Fmoc group is removed by the organic base. Then, there is a beta elimination step, with formation of $\mathrm{CO}_{2}$. The resin without the Fmoc group, formed in the previous step, is then protonated, resulting in the final product of resin with a free $-\mathrm{NH}_{2}$ group (Fig. 4).

This process of deprotection is performed at each stage of the synthesis for the formation of a free $-\mathrm{NH}_{2}$ group, at which the amino acid derivative coupling will occur for peptide bond formation.

\section{Ninhydrin Test}

To verify the previously described deprotection and the coupling of each amino acid derivative during all stages of synthesis, a colorimetric assay for the presence of the amino function group must be conducted. Many assays have been used such as the formation of a salt of the amino group in the resin with picric acid (2,4,6-trinitrophenol) followed by the release of the corresponding phenolate with diisopropylethylamine (Gisisn 1972) or the nucleophilic substitution of halo-1,4-naphtoquinones or nitro, halo-1,4-naphtoquinones with the amino groups linked to solid-phase resins followed by release of 2-amino-3-halo1,4-naphtoquinone by acidolysis (Blackburn 2005). However, there is no assay with so widespread use as the ninhydrin reaction (Shelton and Jensen 2013; Kaiser et al. 1970; Troll and Cannan 1952). This test consists of the reaction of a primary or a secondary amine with ninhydrin, yielding a dark blue compound known as Ruhemann's blue in the former case or a brown compound corresponding to specific non-classic products for secondary amines<smiles>CN(C)C(N(C)C)n1n[n+]([O-])c2ccccc21</smiles>

HBTU<smiles>CCN(C(C)C)C(C)C</smiles>

DIPEA<smiles>CN(C)C=O</smiles>

DMF
Fig. 7 Structures of HBTU, DIPEA and DMF 
(Friedman 2004; McCaldin 1959). In order to perform the test, after deprotection, 1-5 $\mathrm{mg}$ of the obtained product are added to a test tube, then one drop of a solution made with $2 \mathrm{~mL}$ of $\mathrm{KCN}\left(1 \mathrm{mmol} \mathrm{L}^{-1}\right)$ and $98 \mathrm{~mL}$ of pyridine is added, followed by two drops of a $80 \%$ (by weight) phenol solution in ethanol and by one drop of a $5 \%$ (by weight) ninhydrin solution in ethanol (Kaiser et al. 1970; Troll and Cannan 1952). The mixture is heated at $110^{\circ} \mathrm{C}$ for 3-5 min. A color change of the grain sample from faint yellow to blue or brown, for primary and secondary amines, respectively, indicates the presence of a free amino group, and consequently, the deprotection of the resin or peptidyl-resin (Kaiser et al. 1970; Troll and Cannan 1952).

The ninhydrin test can also be used in a quantitative way. For that, as described by Amblard et al. (2006), $5-10 \mathrm{mg}$ of the resin and $1.0 \mathrm{~mL}$ of $20 \%$ piperidine/DMF are added in a tube, stirred for $20 \mathrm{~min}$ and then centrifuged. $100 \mu \mathrm{L}$ of this solution is transferred to a tube containing $10 \mathrm{~mL}$ of DMF and mixed. The resulting solution can be observed by UV spectrometer at $301 \mathrm{~nm}$. The substitution of the resin can be calculated thus: [101 $\times($ Absorbance $)] /$ [7.8 $\times$ (weight in $\mathrm{mg})]$.

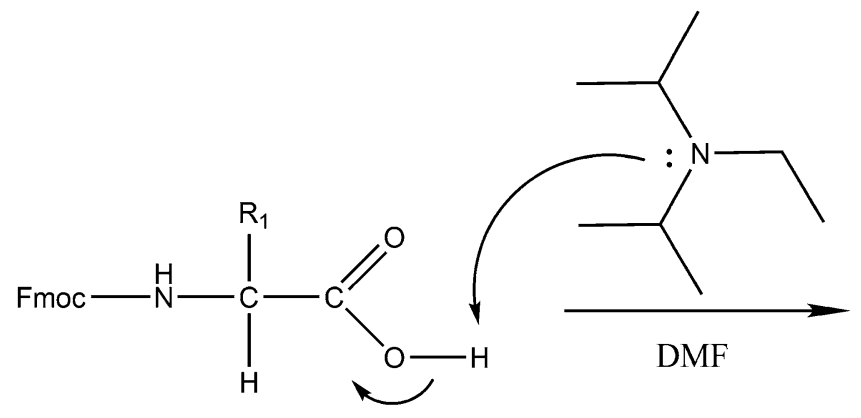<smiles>[R]C(N[R6]F)C(=O)[O-]</smiles><smiles>[R1]C(N[R6](F)(F)F)C(=O)[O-]</smiles><smiles>[R7]C(NC(F)F)C(=O)OCCOC(N(C)C)N(C)C</smiles>

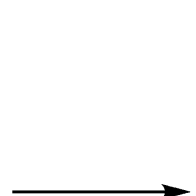<smiles>CNC(=O)F</smiles><smiles>[R]C([CH])[CH][CH][CH]</smiles><smiles>O=COn1nnc2ccccc21</smiles><smiles>CN(C)C(=O)N(C)C</smiles>

\section{Activated Fmoc-amino acid}

Fig. 8 Mechanism for the activation reaction of the Fmoc-amino acid with HBTU, wherein $\mathrm{R}_{1}$ is the side chain of an amino acid (Najera 2002) 
The use of organic solvents in the ninhydrin test, such as alcohols, pyridine and phenol, helps to accelerate the appearance of the color (Troll and Cannan 1952). The visible spectrum of Ruhemann's compound in pyridine is blue-shifted when compared to other solvents like DMF and DMSO. The heating of the mixture near to $100{ }^{\circ} \mathrm{C}$ for up to 5 min gives a quantitative yield for the appearance of color when reacting with a $-\mathrm{NH}_{2}$ of the resin or of the amino acid residue (Troll and Cannan 1952). The reaction mechanism between the primary amino group of an $\alpha$-amino acid and ninhydrin to form the Ruhemann's blue is shown in Fig. 5.

This test can be successfully used for all amino acids, except for proline. In this case, another colorimetric test, also using ninhydrin, can be used, giving a yellow product. The mechanism for the reaction of ninhydrin with proline is shown in Fig. 6.

\section{Coupling of the First Amino Acid Derivative and Peptide Bond Formation}

After deprotection and its confirmation by quantitative nynhidrin test yielding 90-100\% of theoretical value (Kilk and Langel 2006), the synthesis can be started and the first amino acid derivative can be coupled to the resin. Since the synthesis is carried towards the N-terminus (Lloyd-Williams et al. 1993), the nucleophilic group of the resin linker reacts with the acid group of the amino acid derivative while its amino group is protected. For this reason, the last amino acid derivative is added first in the reaction vessel for coupling to the resin. The method and the mechanism of coupling of the Fmoc-amino acid derivative to the resin depend upon the nature of the bond being formed. For the ester bond formation to linkers such as the Wang resin and the HMPB resin it is necessary to use a base as catalyst, for which 4-dimethylaminopyridine is usually employed, with a carbodiimide as the carboxyl-activating reagent (Chan and White 2000). Other coupling reagents that furnish good yield for the esterification were also introduced, such as the chloro derivative 2-chloro, 1,3-dimethylimidazolidinium hexafluorophosphate (CIP) (Akaji et al. 1992). For the very acid-labile 2-chlorotrityl chloride linker, the carboxyl group of the amino acid derivative attacks the methyl carbon and chloride is the leaving group, which leads to the linkage of Fmoc-amino acids to the 2-chlorotrityl chloride resin (Barlos et al. 1989; James 1999). The ideal linker would fulfill a number of important criteria like cost, availability, attachment of starting material should be readily achieved in high yield, stable to the chemistry used in synthesis, cleavage would be efficient under conditions that do not damage the final product(s) and should not introduce impurities that are difficult to remove (James 1999). The choice of the linker requires careful consideration and readers must refer to the James (1999) review for a complete description of the linkers used in solid-phase<smiles>[R10]NCCCCCCCC([R8])C(=O)On1nnc2ccccc21</smiles>

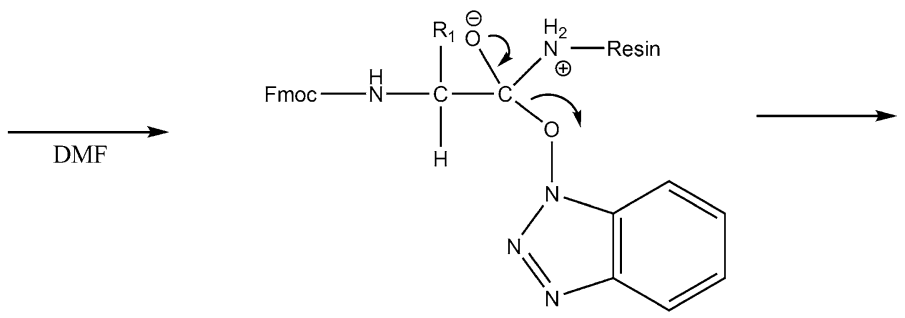

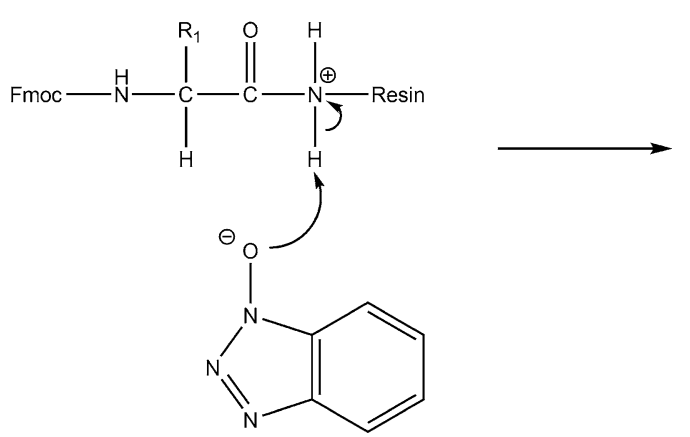<smiles>[R10]NC(=O)C([R7])NC(=O)F</smiles><smiles>On1nnc2ccccc21</smiles>

Fig. 9 Mechanism for the reaction of coupling the activated Fmoc-amino acid to the resin. $\mathrm{R}_{1}$ is the side chain of an amino acid (Montalbetti and Falque 2005) 
(DCCD)

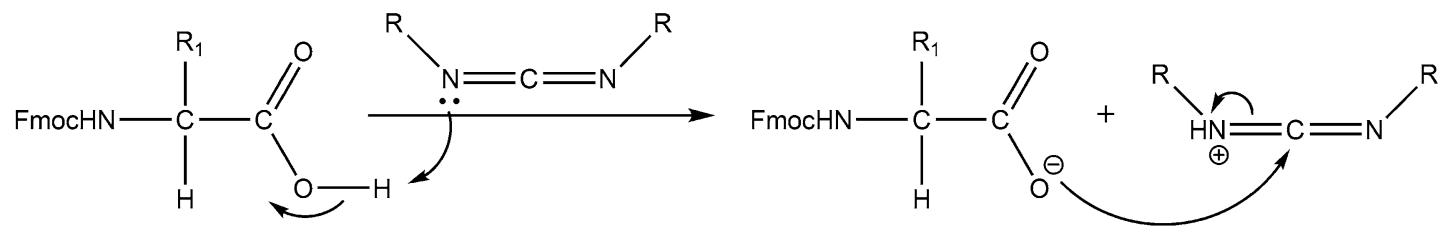

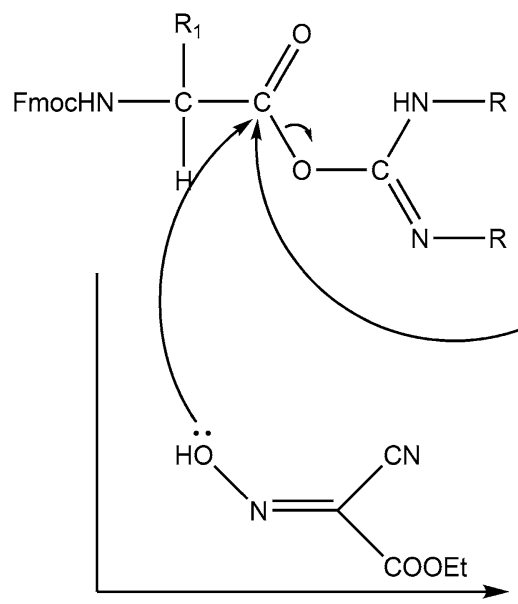

(Oxyma)

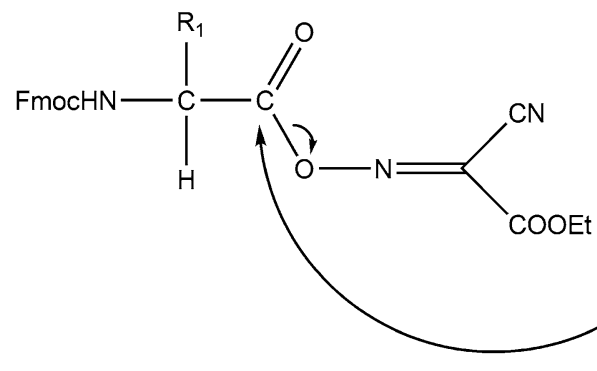

the second amino acid to be coupling with the first and $\mathrm{R}_{3}$ is a peptide chain. (Benoiton, 2005; Al-Warhi et al. 2012; Subirós-Funosas et al. 2009)

peptide bond formation (Najera 2002). The high kinetic barrier for peptide bond formation has as a counterpart, this is the very high stability of the peptide bond formed (Wolfenden 2006). Thus, the formation of the peptide bond and the amide bond to linkers are usually very stable even to some harsh conditions of synthesis. The added activating group is also a good leaving group that favors the reaction kinetically (Montalbetti and Falque 2005).

The suggested mechanism for the reaction of the activation of the amino acid derivative with the aminium-type reagent HBTU and the proton removal by DIPEA is shown in Fig. 8. Initially, the acidic proton of the Fmoc-amino acid is removed by DIPEA or other organic base. Then, the deprotonated Fmocamino acid is added to HBTU, generating the elimination of a triazole derivative. Finally, this hydroxybenzotriazole derivative is added to the carbonyl group of the Fmoc-amino acid, leading to the formation of the final product, the activated Fmoc-amino acid, by nucleophilic substitution. Very similar mechanisms are valid for other aminium type reagents like TBTU ([benzotriazol-1-yloxy(dimethylamino) methylidene]dimethylazanium trifluoroborane fluoride) and HATU 
Table 1 Molecular weight of Fmoc-amino acids with protecting groups, free amino acids and amino acids within a peptide
Fig. 11 Scheme for coupling an Fmoc-amino acid to another amino acid residue already attached to the resin. $R_{1}$ and $R_{2}$ are side chains of two different amino acids being linked

\begin{tabular}{lllc}
\hline & $\begin{array}{l}\text { MW }(\mathrm{g} / \mathrm{mol}) \\
\text { Fmoc-amino acid }\end{array}$ & $\begin{array}{l}\text { MW }(\mathrm{g} / \mathrm{mol}) \\
\text { Free-amino acid }\end{array}$ & $\begin{array}{l}\text { MW }(\mathrm{g} / \mathrm{mol}) \\
\text { Amino acid within a peptide }\end{array}$ \\
\hline Fmoc-Ala-OH & 311.3 & 89.1 & 71.1 \\
Fmoc-Arg(Pbf)-OH & 648.8 & 174.2 & 156.2 \\
Fmoc-Asn(Trt)-OH & 596.7 & 132.1 & 114.1 \\
Fmoc-Asp(OtBu)-OH & 411.5 & 133.1 & 115.1 \\
Fmoc-Cys(Trt)-OH & 585.7 & 121.2 & 103.2 \\
Fmoc-Glu(tBu)-OH & 443.5 & 147.1 & 129.1 \\
Fmoc-Gln(Trt)-OH & 610.7 & 146.1 & 128.1 \\
Fmoc-Gly-OH & 297.3 & 75.1 & 57.1 \\
Fmoc-His(Trt)-OH & 619.7 & 155.1 & 137.1 \\
Fmoc-Ile-OH & 353.4 & 131.2 & 113.2 \\
Fmoc-Leu-OH & 353.4 & 131.2 & 113.2 \\
Fmoc-Lys(Boc)-OH & 468.5 & 146.2 & 128.2 \\
Fmoc-Met-OH & 371.5 & 149.2 & 131.2 \\
Fmoc-Pro-OH & 337.4 & 115.1 & 97.1 \\
Fmoc-Phe-OH & 387.4 & 165.2 & 147.2 \\
Fmoc-Ser( $t \mathrm{Bu})-\mathrm{OH}$ & 383.4 & 105.1 & 87.1 \\
Fmoc-Thr( $t \mathrm{Bu}) \mathrm{OH}$ & 397.5 & 119.1 & 101.1 \\
Fmoc-Trp(Boc)-OH & 526.6 & 204.2 & 186.2 \\
Fmoc-Tyr $t$ Bu)-OH & 459.6 & 181.2 & 163.2 \\
Fmoc-Val-OH & 339.4 & 117.1 & 99.1 \\
\hline
\end{tabular}

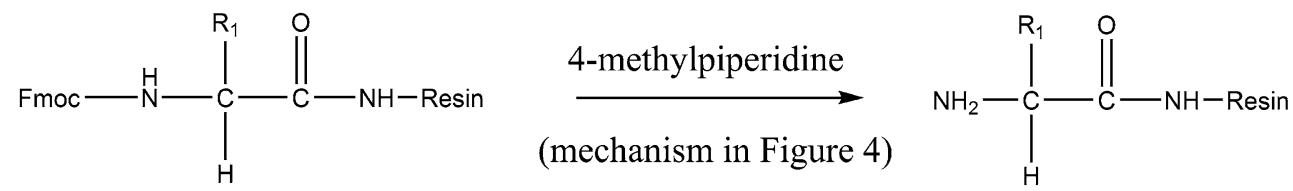<smiles>[R10]NC(=O)C([R])N</smiles><smiles>[R2]C([2H])(NC(=O)F)C(=O)O</smiles>

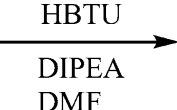

(mechanism in Figures 7 and 8)<smiles>[R16]NC(=O)C([R7])NC(=O)C([R2])([2H])N[R16]#P</smiles>

([dimethylamino(triazolo[4,5-b]pyridin-3-yloxy)methylidene]-dimethylazanium hexafluorophosphate) and phosphonium-type BOP (benzotriazol-1-yloxy-tris(dimethylamino)phosphanium hexafluorophosphate) and PyBOP (benzotriazol-1-yloxy(tripyrrolidin-1-yl)phos phanium hexafluorophosphate).

Another method for coupling reaction can be performed by esterification of the carboxylic acid with 2,4,6-mesitylene-sulfonyl-3-nitro-1,2,4-triazol (MSNT) in the presence of 1-methylimidazol (Melm) (Blankemeyer-Menge et al. 1990). This procedure for anchoring Fmoc-amino acids to hydroxyl solid supports can achieve high yields and prevent the formation of dipeptide and racemization (Blankemeyer-Menge et al. 1990).

With the activated Fmoc-amino acid, it is possible to carry out the coupling of this activated compound to the resin or to another protected amino acid. The mechanism for the coupling reaction of an activated Fmoc-amino acid 
<smiles>CSc1ccccc1</smiles>

Thioanisole

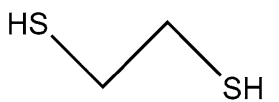

EDT

Fig. 12 Structures of thioanisole and EDT

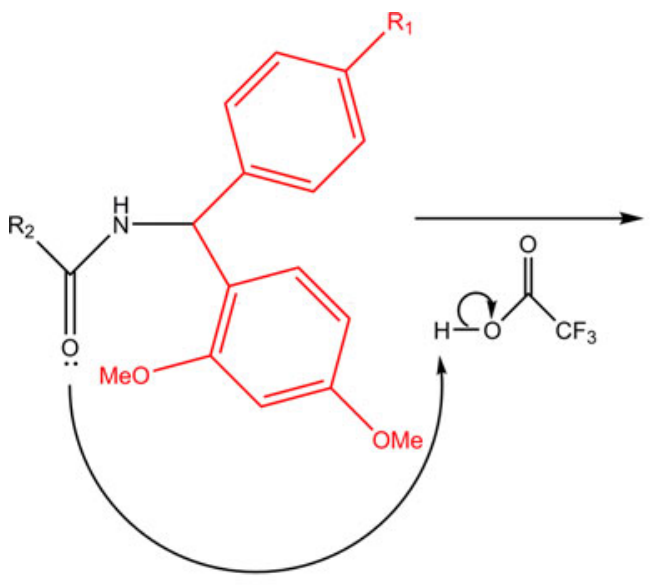

to the resin is shown in Fig. 9. At first it takes place the nucleophilic substitution: the $-\mathrm{NH}_{2}$ group of the resin is added to the acyl carbon of the activated Fmoc-amino acid, followed by the elimination of 1-hydroxybenzotriazole after a proton transfer from the aminium group of the resin linker. As a result, there is the coupling of the Fmoc-amino acid to the resin. An analogous mechanism occurs for the peptide bond formation.

The other very widespread method for amino acid derivative activation is by means of carbodiimide, usually in the presence of a hydroxylamine derivative. There are

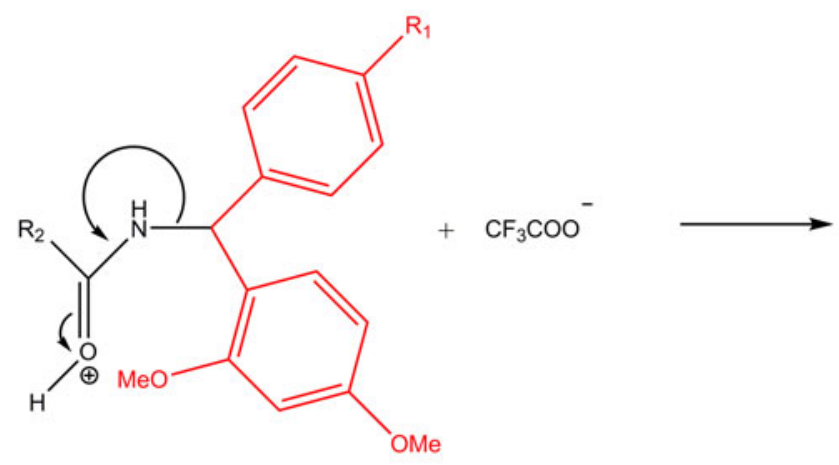

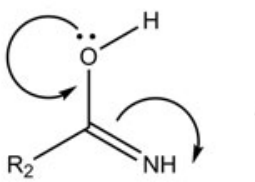

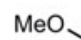<smiles>[R]C(N)=O</smiles><smiles>C[14CH2]NC</smiles>

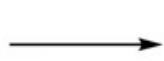<smiles>[R]C(N)=O</smiles><smiles></smiles>

Fig. 13 Reaction mechanism to remove the resin by TFA (Brady et al. 1977). In red, the linker structure to be removed by cleavage for the formation of amidated peptide. $R_{1}$ is the resin chain, $R_{2}$ is a

peptide chain and $\mathrm{Nu}$ is a nucleophilic compound (see Fig. 10) present in the cleavage process (Color figure online) 
Fig. 14 Removal of $t$-butyl group of serine. In red, the group to be removed. $R_{1}$ and $R_{2}$ are peptide chains and $\mathrm{Nu}$ is a nucleophile compound present in the cleavage process (Brady et al. 1977) (Color figure online)

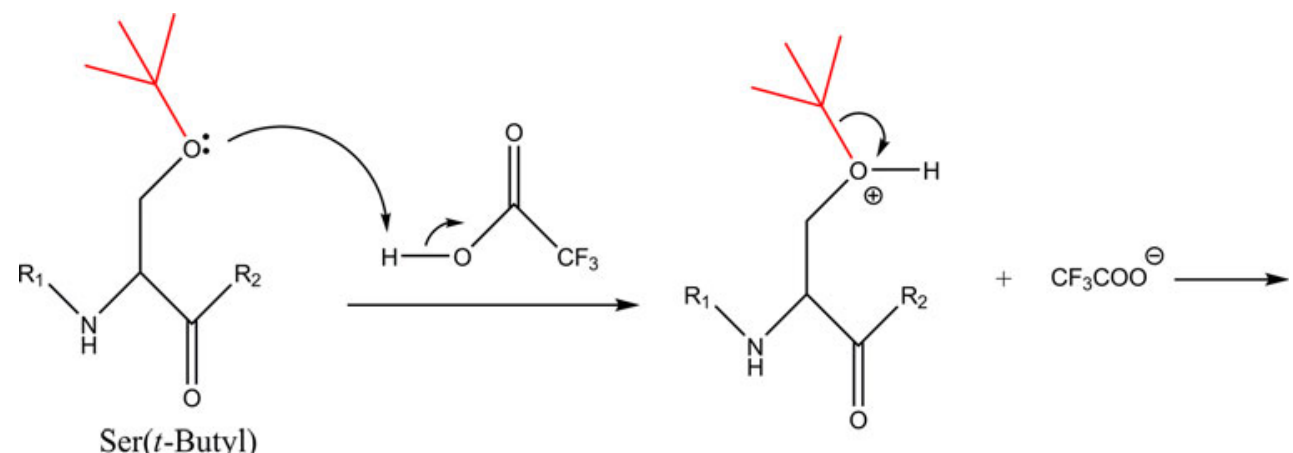<smiles>[R]NC(CO)C([R2])=O</smiles>

Serine<smiles>[R]NC(Cc1cn(C(=O)OC(C)(C)C)c2ccccc12)C([R1])=O</smiles>

$\operatorname{Trp}(\mathrm{Boc})$<smiles>[R]NC(Cc1c[nH]c2ccccc12)C([R7])=O</smiles><smiles>CC(C)(C)CC#N</smiles><smiles>[R]NC(Cc1c[nH]c2ccccc12)C([R])=O</smiles>

Tryptophan

Fig. 15 Removal of Boc group from the protected tryptophan. In red, the group that will be removed. $\mathrm{R}_{1}$ and $\mathrm{R}_{2}$ are peptide chains and $\mathrm{Nu}$ is a nucleophile compound present in the cleavage process (Brady et al. 1977) (Color figure online) 
Fig. 16 Structure of TIS<smiles>CC(C)[SiH](C(C)C)C(C)C</smiles>

TIS

many carbodiimides available in the literature, but the most widely used is 1,3-diisopropylcarbodiimide, whose side product is a urea that is soluble in DMF and DCM. Nevertheless, it is not advisable to couple amino acid derivatives only in the presence of the carbodiimide since this usually leads to a high level of enantiomerization through an oxazolone intermediate (Montalbetti and Falque 2005; Wolfenden 2006; Benoiton 1996) stabilized by resonance. In fact, 2-phenyl-5-oxazolone (Yalcin et al. 1995), which is a useful reference compound for peptide fragmentation in mass spectrometry, is being prepared by activation with a carbodiimide, which clearly shows a straightforward formation of oxazolones by carbodiimide. The mechanism of carboxyl group activation is shown in Fig. 10. The carboxyl group performs a nucleophilic attack of the electrophilic carbon of carbodiimide, which occurs together with a proton transfer. Since the carbodiimide has a basic nitrogen capable of accepting the carboxyl proton, one of the advantages of this reagent compared to aminium or phosphonium salts is that it is not necessary to add an organic base to generate the carboxylate. Nevertheless, the $O$-acyl isourea formed is activated (i.e. it has a very good leaving group and a high free energy content), which favours the oxazole formation and amino acid enantiomerization. A hydroxylamine is usually added to prevent enantiomerization by converting the $O$-acyl isourea into a less active intermediate. 1-hydroxybenzotriazole and other triazole derivatives such as 1-hydroxy-7-azabenzotriazole (Chan and White 2000; Carpino 1993) are very efficient suppressors of racemization, but triazoles may be explosive under certain conditions, which made the international transport of those chemicals difficult. Fortunately, the reagent ethyl (2Z)-2-cyano-2-hydroxyiminoacetate (the socalled Oxyma) was recently introduced as a safe and efficient suppressor of enantiomerization (Subirós-Funosas et al. 2009). Like the benzotriazoles, oxyma has an hydroxylamine function which performs a nucleophilic attack on the $O$-acyl isourea amino acid derivative forming an active ester (Fig. 10).

As the first amino acid residue bound to the resin or the amino acid residue introduced has the temporary protecting group, in our case the Fmoc group, the deprotection should be carried out again with 4-methylpiperidine/DMF (1/4,
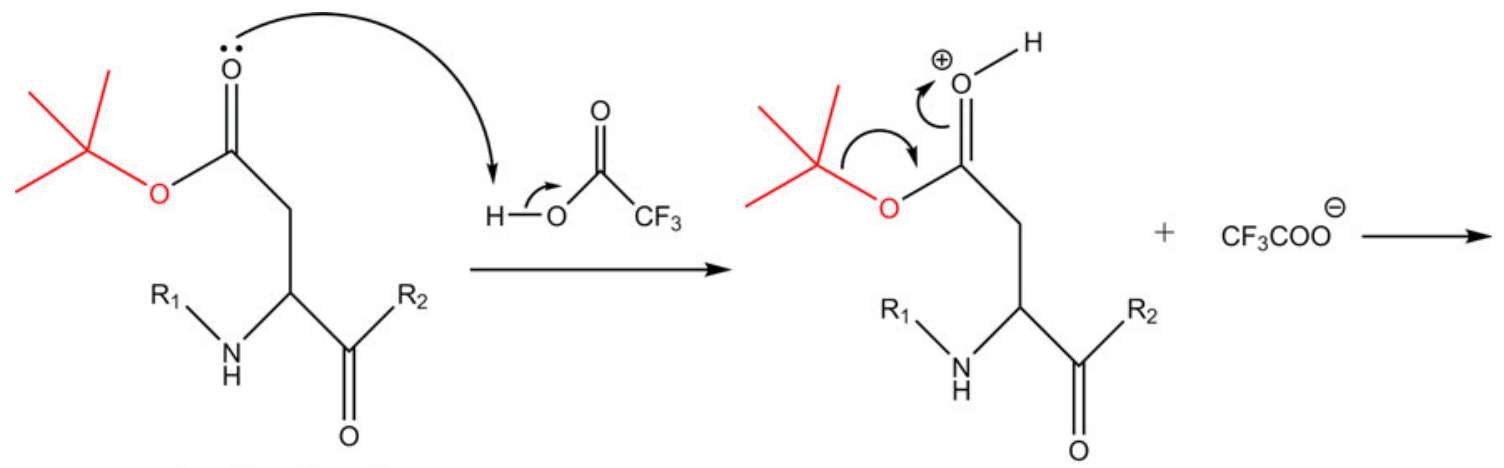

Asp(O-t-Butyl)
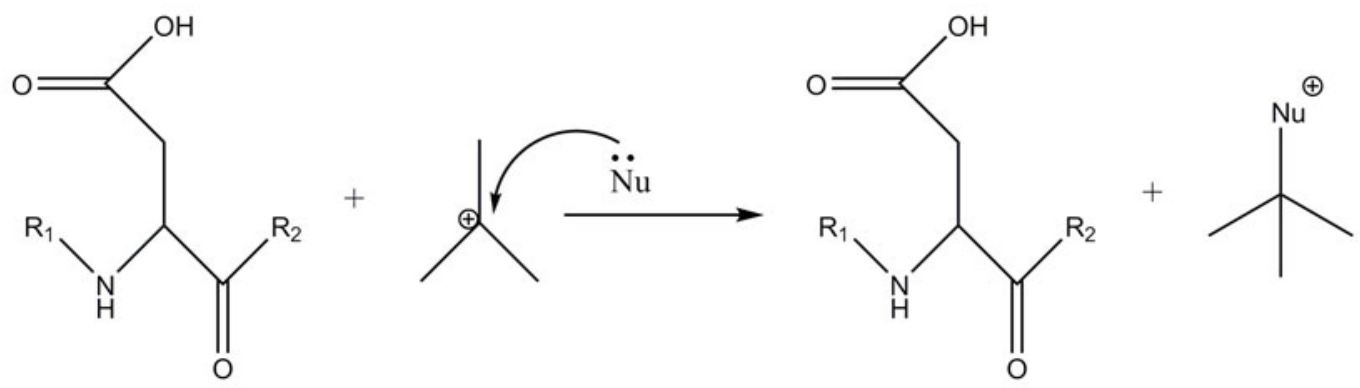

Aspartic acid

Fig. 17 Removal of O- $t$-butyl group from the protected aspartic acid. In red, the group that will be removed. $\mathrm{R}_{1}$ and $\mathrm{R}_{2}$ are peptide chains and $\mathrm{Nu}$ is a nucleophilic compound present in the cleavage process (Color figure online) 


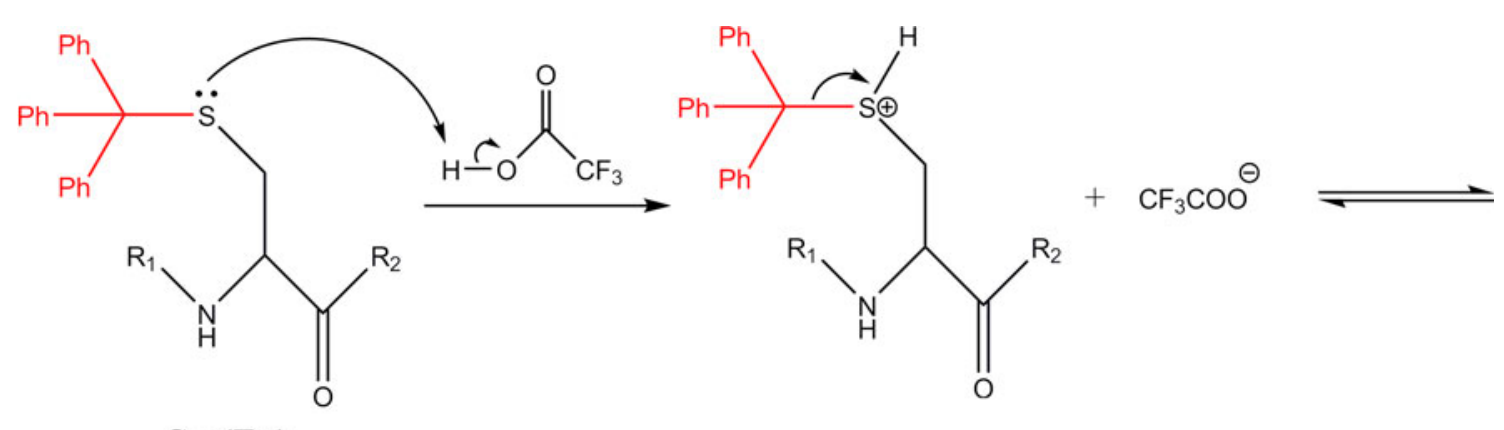

Cys(Trt)

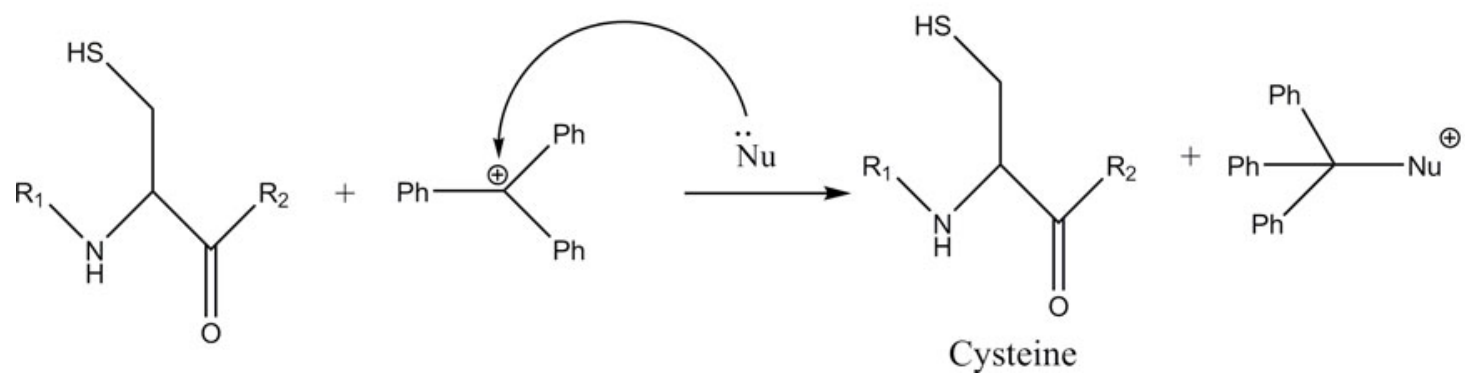

Fig. 18 Removal of Trt group from the protected cysteine. The group that will be removed is represented in red. $R_{1}$ and $R_{2}$ are peptide chains and $\mathrm{Nu}$ is a nucleophilic compound present in the cleavage process that scavengers the carbocation (Benoiton 2005) (Color figure online)

$\mathrm{v} / \mathrm{v}$ ) for the removal of this group (as previously described) and making it possible to continue the synthesis and the coupling of the following Fmoc-amino acid. To check if the amino acid residue is without the Fmoc group (i.e. with a free amino group), the ninhydrin test must be held again.

The 20 most common Fmoc-amino acids that can be used on solid-phase synthesis are listed in Table 1, showing also the permanent protecting group (i.e., side chain) and their molecular weight. The side chain permanent protecting group is only removed in the final cleavage step that is discussed in the next session. If the side chain protecting group remains bound to the peptide, the mass addition can easily be detected by mass spectrometry (Table 1).

A scheme for coupling an Fmoc-amino acid to another amino acid residue already attached to the resin is shown in Fig. 11.

\section{Cleavage}

After performing the coupling of all Fmoc-amino acids of the peptide sequence, the next step is the process of cleavage for removing the resin and the side chains protecting groups (Fig. 2) and thus obtain the desired peptide, free of any protecting group or structural modification, except for special cases when a side chain protected peptide is necessary, as in the fragment condensation, orthogonal protection or modification and folding, among others. Our discussion will be focused on the methods applied to acid-labile linkers compatible with the Fmoc strategy. For the cleavage and removal of a permanent protecting group, the experimental procedure consists of adding to a tube the peptidyl-resin and a solution containing trifluoroacetic acid (TFA) in the presence of carbocation scavengers. When the peptide contains side chains prone to alkylation, such as sulfhydryl, thioether, indole and phenol, the use of a mixture of different nucleophilic scavengers is recommended (King et al. 1990). Examples of popular mixtures are $81.5 \%$ TFA, $5 \%$ thioanisole, $5 \%$ phenol, $5 \%$ water, $2.5 \%$ ethanedithiol (EDT), and $1 \%$ TIS (by volume) or $92.5 \%$ TFA, $2.5 \%$ water, $2.5 \%$ TIS and $2.5 \%$ EDT (Fields and Noble 1990; Chan and White 2000; Benoiton 2005). The mixture is allowed to react under stirring for $90 \mathrm{~min}$. After completing the reaction, nitrogen gas is bubbled into the solution to evaporate most of the solvents. With positive pressure via nitrogen, the cleaved peptide is then washed, preferably with cold diisopropyl ether. Then, the peptide is extracted with an aqueous solution of acetonitrile ( $50 \%$ by volume $+0.1 \%$ TFA, for keeping the peptide under slight acidic condition) and freeze-dried. Upon lyophilization, the synthetic peptide can be characterized by mass spectrometry (Karas and Hillenkanp 1988; Fen et al. 1989; Biemann and Papayannopoulos 1994).

The process of cleavage by TFA leads to the formation of carbocations that are highly reactive intermediates. They may specifically react with side chains of tyrosine, 


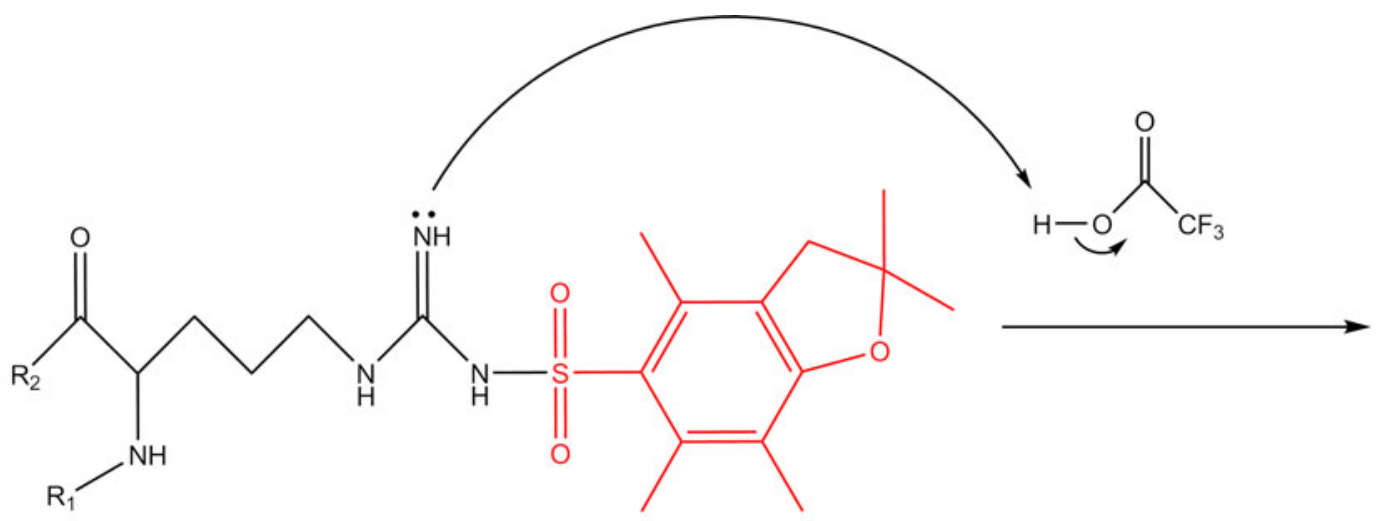

$\operatorname{Arg}(\mathrm{Pbf})$

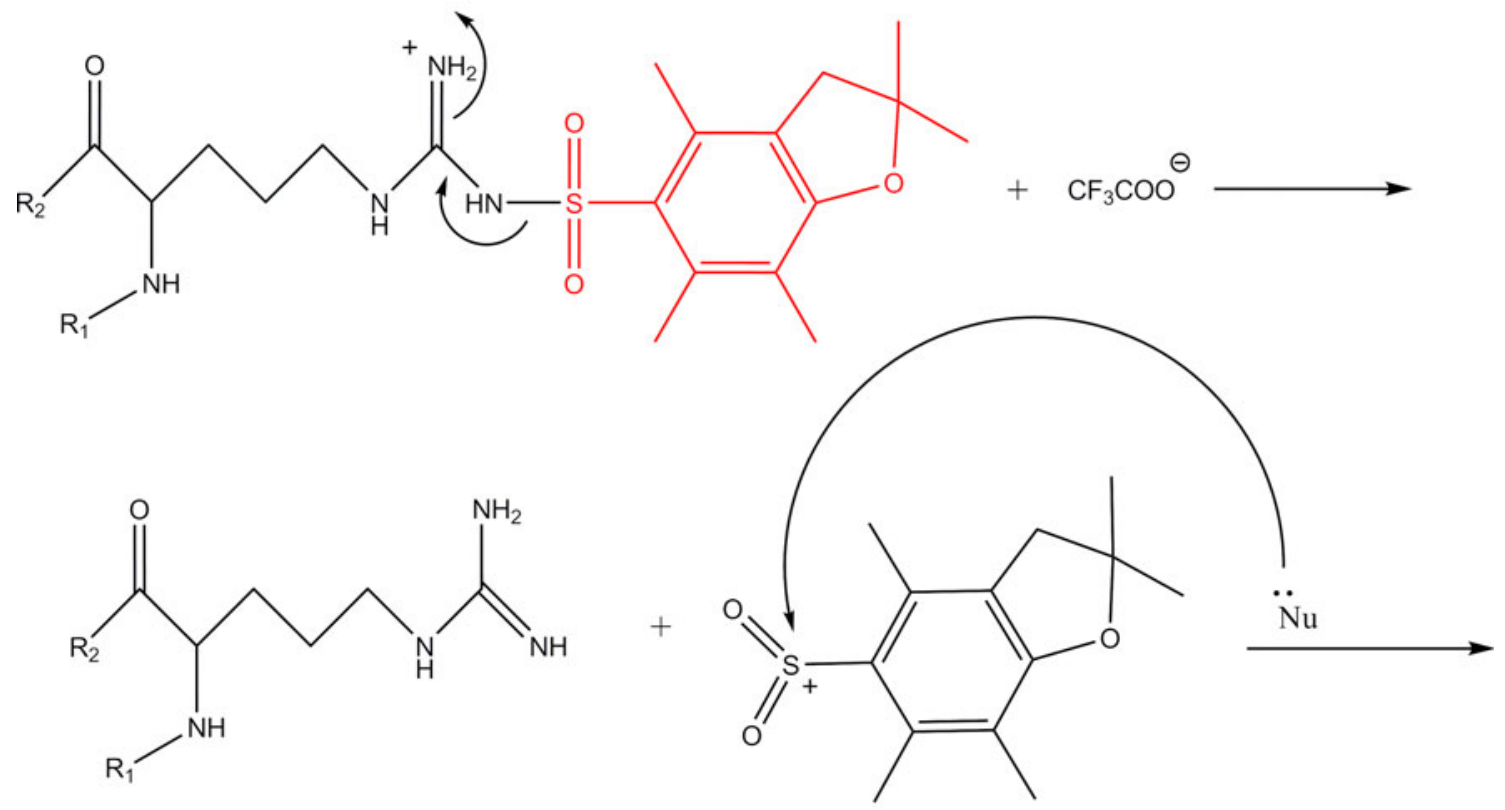<smiles>[R]NC(CCCNC(=N)N)C([R])=O</smiles><smiles>Cc1c(C)c(S([NH3+])(=O)=O)c(C)c2c1OC(C)(C)C2</smiles>

Arginine

Fig. 19 Removal of Pbf group from the protected arginine. In red, the group that will be removed. $\mathrm{R}_{1}$ and $\mathrm{R}_{2}$ are peptide chains and $\mathrm{Nu}$ is a nucleophilic compound present in the cleavage process (Carpino et al. 1993) (Color figure online)

tryptophan, methionine and cysteine (which are rich in electrons) generating undesirable products (Chan and White 2000). To prevent this, good nucleophilic species are added to the cleavage reaction, such as thioanisole (methylsulfanylbenzene) and 1,2-ethanedithiol (EDT) (Chan and White 2000), whose structures are shown in Fig. 12. The reaction mechanism for the cleavage by acidolysis of a Rink-amide type peptidyl-resin linkage is shown in Fig. 13.

Fmoc-amino acids such as serine, threonine, and cysteine derivatives, among others, have not only alkyl groups in their side chain but also contain reactive functional groups that need permanent protection (Fig. 2) in order to 
prevent unwanted reactions in these groups throughout the synthesis. These protecting groups must be removed in this final process of cleavage.

The cleavage of $t$-butyl and Boc protecting groups (Fig. 2) leads to the formation of $t$-butyl cations by a $S_{N} 1$ reaction. The proposed mechanisms are shown in Figs. 14 and 15, respectively. The t-butyl carbocation is one of the most stable among common alkyl or aryl groups (March 1992). Thus, despite still being an transient specie, it has a sufficiently long lifetime to alkylate electron-rich peptide moieties. This means these carbocations may react with tryptophan, leading to its alkylation (Fields and Noble 1990). To avoid this reaction, EDT is added to the cleavage process to sequester $t$-butyl cations. To completely prevent alkylation of tryptophan, thioanisole (methylsulfanylbenzene) is also very efficient and thus it is employed as a second scavenger (Fields and Noble 1990).

The cleavage of the Trt group from cysteine is reversible without the presence of carbocation receptors (Fields and Noble 1990). Triphenylmethyl (or Trt) is a well-studied carbocation that has a non-planar structure with a central carbon with a high charge density accordingly to its NMR carbon chemical shift data (March 1992). To avoid this reversibility, phenol and triisopropylsilane (tri(propan-2yl)silicon, TIS (structure shown in Fig. 16) are added to the cleavage process (Fields and Noble 1990). The mechanisms for the removal of the protecting groups $O$ - $t$-butyl, Trt and Pbf are shown in Figs. 17, 18 and 19, respectively.

Although (Carpino et al. 1993) gives evidences of a $\mathrm{S}_{\mathrm{N}} 1$ reaction for the removal of Pbf group, Han et al. (1996) suggests that some scavengers are necessary to remove this group, indicating a possibility of a $\mathrm{S}_{\mathrm{N}} 2$ reaction.

All the mechanisms showed before for the process of the cleavage for the removal of the side-chain protecting groups (Figs. 13, 14, 15, 17, 18, 19) involves the acceptance of the acidic proton from TFA by the most basic electron-pair of the protected amino acid. This leads to the elimination of the protecting group as a highly reactive carbocation, which promptly reacts with the nucleophiles scavenger present in the reaction medium (e.g. EDT, thioanisole and TIS).

\section{Conclusion}

SPPS is the method of choice to introduce non-natural peptides.

This paper presents all the stages of the synthesis using the Fmoc strategy, while also addressing the mechanisms involved in each step, which can enable a better understanding of this process. This short review can also be used in basic organic chemistry courses for biology students, contextualizing and exemplifying some organic reactions in the synthesis of peptides.

Acknowledgments The authors are thankful to Andrew William Gerard Murray for the English revision.

Conflict of interest The authors declare that they have no conflict of interest.

Compliance With Ethics This article does not contain any studies with human or animal subjects.

\section{References}

Akaji K, Kuriyama N, Kimura T, Fujiwara Y, Kiso Y (1992) Anchoring of Fmoc amino scid to 4-alkoxybenzyl alcohol resin using a new esterification reagent. Tetrahed Lett 33:3177-3180

Albericio F (2004) Developments in peptide and amide synthesis. Curr Opin Chem Biol 8:211-221

Al-Warhi TI, Al-Hazimi HMA, El-Faham A (2012) Recent development in peptide coupling reagents. J Saudi Chem Soc 16:97-116

Amblard M, Fehrentz JA, Martinez J, Subra G (2005) Fundamentals of modern peptide synthesis. Methods Mol Biol 218:3-24

Amblard M, Fehrentz JA, Martinez J, Subra G (2006) Methods and protocols of modern solid phase peptide synthesis. Mol Biotechnol 33:239-253

Aucagne V, Valverde IE, Marceau P, Galibert M, Dendane N, Delmas AF (2012) Towards the simplification of protein synthesis: iterative solid-supported ligations with concomitant purifications. Angew Chem Int Ed 51:11320-11324

Barlos K, Gatos D, Kallitsis J, Papaphotiu G, Sotiriu P, Yao W, Schaefer W (1989) Preparation of protected peptide fragments using triphenylmethyl resins. Tetrahedron Lett 30:3943-3946

Benoiton NL (1996) 2-Alkoxy-5(4H)-oxazolones and the enantiomerization of $\mathrm{N}$-alkoxycarbonylamino acids. Biopolymers 40:245-254

Benoiton NL (2005) Chemistry of peptide synthesis. Taylor and Francis, Boca Raton

Biemann K, Papayannopoulos IA (1994) Amino acid sequencing of proteins. Acc Chem Res 27:370-378

Blackburn C (2005) Solid-phase synthesis of 2-amino-3-chloro-5- and 8-nitro-1,4-naphthoquinones: a new and general colorimetric test for resin-bound amines. Tetrahed Lett 46:1405-1409

Blankemeyer-Menge B, Nimtz M, Frank R (1990) An efficient method for anchoring Fmoc-amino acids to hydroxyl-functionalised solid supports. Tetrahed Lett 31(12):1701-1704

Bong DT, Clark TD, Granja JR, Ghadiri MR (2001) Self-assembling organic nanotubes. Angew Chem Int 16:988-1011

Brady SF, Hirschmann R, Veber DF (1977) Some novel acid-labile amine protecting groups. J Org Chem 42:143-146

Brogden KA (2005) Antimicrobial peptides: pore formers or metabolic inhibitors in bacteria? Nature Rev 3:238-250

Carpino L (1987) The 9-fluorenylmethyloxycarbonyl family of basesensitive amino-protecting groups. Acc Chem Res 20:401-407

Carpino LA (1993) 1-Hydroxy-7-azabenzotriazole. an efficient peptide coupling additive. J Am Chem Soc 115:4397-4398

Carpino LA, Han GY (1972) The 9-Fluorenylmethoxycarbonyl amino-protecting group. J Org Chem 37:3404-3409

Carpino LA, Shroff H, Triolo SA, Mansour EME, Wenschuh H, Albericio F (1993) The 2,2,4,6,7-Pentamethyldihydrobenzofuran-5-sulfonyl Group (Pbf) as arginine side chain protectant. Tetrahedr Lett 34:7829-7831 
Chan WC, White PD (2000) Fmoc solid phase peptide synthesis. PAS, Oxford

Chen P (2005) Self-assembly of ionic-complementary peptides: a physicochemical viewpoint. Colloids Surf A 261:3-24

Elsawy MA, Hewage C, Walker B (2012) Racemisation of N-Fmoc phenylglycine under mild microwave-SPPS and conventional stepwise SPPS conditions: attempts to develop strategies for overcoming this. J Pept Sci 18:302-311

Fen JB, Man M, Meng CK, Wong SF, Whitehouse CM (1989) Electrospray ionization for mass spectrometry of large biomolecules. Science 246:64-71

Fields GB, Noble RL (1990) Solid phase peptide synthesis utilizing 9-fluorenylmethoxycarbonyl amino acids. Int J Pept Protein Res 35:161-214

Friedman M (2004) Applications of the ninhydrin reaction for analysis of Amino acids, peptides, and proteins to agricultural and biomedical Sciences. J Agric Food Chem 52:385-406

Gisisn BT (1972) The monitoring of reactions in solid-phase peptide synthesis with picric acid. Anal Chim Acta 58:248-249

Goldberg JS (2010) Stereochemical basis for a unified structure activity theory of aromatic and heterocyclic rings in selected opioids and opioid peptides. Pers Med Chem 4:1-10

Gońgora-Benítez M, Tulla-Puche J, Albericio F (2013) Handles for Fmoc solid-phase synthesis of protected peptides. ACS Comb Sci 15:217-228

Gravert DJ, Janda KD (1997) Organic synthesis on soluble polymer supports: liquid-phase methodologies. Chem Rev 97:489-509

Hachmann J, Lebl M (2006) Alternative to piperidine in Fmoc solidphase synthesis. J Comb Chem 8(2): 149-149

Han Y, Bontems SL, Hegyes P, Munson MC, Minor CA, Kates SA, Albericio F, Barany G (1996) Preparation and applications of Xanthenylamide (XAL) handles for solid-phase synthesis of c-terminal peptide amides under particularly mild conditions. J Org Chem 61:6326-6339

Hancock REW, Scott MG (2000) The role of antimicrobial peptides in animal defenses. Proc Natl Acad Sci USA 97:8856-8861

Hibino H, Nishiuchi Y (2012) 4-Methoxybenzyloxymethyl group, a racemization-resistant protecting group for cysteine in Fmoc solid phase peptide synthesis. Org Lett 14:1926-1929

Howl J (2005) Peptide synthesis and applications. Humana Press, New York

Hudson D (1988) Methodological implications of simultaneous solidphase peptide synthesis-comparison of different coupling procedures. J Org Chem 53:617-624

Isidro-Llobet A, Alvarez M, Alberico F (2009) Amino acid-protecting groups. Chem Rev 109:2455-2504

James IW (1999) Linkers for solid phase organic synthesis. Tetrahedron 55:4855-4946

Jensen KJ (2013) Solid-phase peptide synthesis: an introduction. Methods Mol Biol 1047:1-22

Kaiser E, Colescott RL, Bossinger CD, Cook PI (1970) Color test for detection of free terminal amino groups in the solid-phase synthesis of peptide. Anal Biochem 34:595-598

Karas M, Hillenkanp F (1988) Laser desorption ionization of proteins with molecular masses exceeding 10,000 daltons. Anal Chem 60:2299-2301

Kaupp G, Naimi-Jamal MR, Schmeyers J (2002) Quantitative reaction cascades of ninhydrin in the solid state. Chem Eur $\mathrm{J}$ 8(3):594-600

Kilk K, Langel Ü (2006) Cellular delivery of peptide nucleic acid by cell-penetrating Peptides. Methods Mol Biol 218:131-142

King DS, Fields CG, Fields GB (1990) A cleavage method which minimizes side reactions following Fmoc solid phase peptide synthesis. Int J Pept Prot Res 36:255-266

Lloyd-Williams P, Albericio F, Giralt E (1993) Convergent solidphase peptide synthesis. Tetrahedron 49:11065
Machado A, Liria CW, Proti PB, Remuzgo C, Miranda MTM (2004) Síntese química e enzimática de peptídeos: princípios básicos e aplicações. Quim Nova 37:781-789

March J (1992) Advanced organic chemistry. John Wiley \& Sons, New York

Marquardt M, Eifler-Lima VL (2001) A síntese orgânica em fase sólida e seus suportes poliméricos mais empregados. Quim Nova 24:846-855

McCaldin DJ (1959) The chemistry of ninhydrin. Chem Rev 1:39-51

Menezes MC, Oliveira AK, Melo RL, Ferreira ML, Rioli V, Balan A, Leme AFP, Serrano SMT (2011) Disintegrin-like/cysteine-rich domains of the reprolysin HF3: site-directed mutagenesis reveals essential role of specific residues. Biochimie 93:345-351

Mergler M, Dick F (2005) The aspartimide problem in Fmoc-based SPPS. part III. J Peptide Sci 11:650-657

Merrifield RB (1963) Solid phase peptide synthesis-the synthesis of a tetrapeptide. J Am Chem Soc 85:2149-2154

Miranda LP, Alewood PF (1999) Accelerated chemical synthesis of peptides and small proteins. Proc Natl Acad Sci 96:1181-1186

Montalbetti CGN, Falque V (2005) Amide bond formation and peptide coupling. Tetrahedron 740:10827-10851

Naidoo VB, Rautenbach M (2012) Bidirectional solid phase synthesis of a model oligoglycine bolaamphiphile and purification by rapid self-assembly. J Pept Sci 18:317-325

Najera C (2002) From $\alpha$-Amino acids to peptides: all you need for the journey. Synlett 9:1388-1402

Pedersen SL, Jensen KJ (2013) Instruments for automated peptide synthesis. Methods Mol Biol 1047:43-63

Plaquevent JC, Levillain J, Guillen F, Malhiac C, Gaumont AC (2008) Ionic liquids: new targets and media for alpha-amino acid and peptide chemistry. Chem Rev 108:5035-5060

Remuzgo C, Andrade GFS, Temperini MLA, Miranda MTM (2009) Acanthoscurrin fragment 101-132: total synthesis at $60^{\circ} \mathrm{C}$ of a novel difficult sequence. Biopolym Pept Sci 92:65-75

Schnolzer M, Alewood P, Jones A, Alewood D, Kent SBH (2007) In situ neutralization in Boc-chemistry solid phase peptide synthesis. Int J Pept Res Ther 13:31-44

Shelton PT, Jensen KJ (2013) Linkers, resins, and general procedures for solid-phase peptide synthesis. Methods Mol Biol 1047:23-42

Subirós-Funosas R, Prohens R, Barbas R, El-Faham A, Albericio F (2009) Oxyma: an efficient additive for peptide synthesis to replace the benzotriazole-based HOBt and HOAt with a lower risk of explosion. Chem Eur J 15:9394-9403

Tailhades J, Gidel MA, Grossi B, Lécaillon J, Brunel I, Subra G, Martinez J, Amblard M (2010) Synthesis of peptide alcohols on the basis of an $O-N$ acyl-transfer reaction. Angew Chem Int Ed 49:117-120

Takahashi D, Yamamoto T (2012) Development of an efficient liquidphase peptide synthesis protocol using a novel fluorene-derived anchor support compound with Fmoc chemistry. Tetrahed Lett 53:1936-1939

Tietze AA, Heimer P, Stark A, Imhof D (2012) Ionic liquid applications in peptide chemistry: synthesis, purification and analytical characterization processes. Molecules 17:4158-4185

Troll W, Cannan RK (1952) A modified photometric ninhydrin method for the analysis of amino and imino acids. J Biol Chem $1: 803-811$

Wolfenden R (2006) Degrees of difficulty of water-consuming reactions in the absence of enzymes. Chem Rev 106:3379-3396

Yalcin T, Khouw C, Csizmadia IG, Peterson MR, Harrison AG (1995) Why are B ions stable species in peptide spectra? J Am Soc Mass Spectrom 6:1165-1174

Zalipsky S, Chang JL, Albericio F, Barany G (1994) Preparation and applications of polyethylene glycol-polystyrene graft resin supports for solid-phase peptide synthesis. React Funct Polym $22: 243-258$ 
Zasloff M (2002) Antimicrobial peptides of multicellular organisms. Nature 415:389-395

Zhang T, Li Y, Miao M, Jiang B (2011) Purification and characterisation of a new antioxidant peptide from chickpea (Cicer arietium L.) protein hydrolysates. Food Chem 128:28-33

Zhang Y, Muthana SM, Farnsworth D, Ludek O, Adams K, Barchi JJ Jr, Gildersleeve JC (2012) Enhanced epimerization of glycosylated amino acids during solid-phase peptide synthesis. J Am Chem Soc 134:6316-6325 